\title{
МІЖГАЛУЗЕВІ ТЕРМІНИ В УКРАЇНСЬКІЙ НАУКОВО-ТЕХНІЧНІЙ ТЕРМІНОЛОГІЇ
}

Анотована стаття присвячена дослідженню міжгалузевих термінів, щз вживаються в украӥнській науково-технічній термінологї̈ з одним або кількома значеннями. З'ясовано, що поява таких одиниць пов'язана з розгалуженістю та реінтеграцією науково-технічних знань. Проаналізовано значення мінгалузевих спеціальних одиниць в різних сферах науки і техніки. Доведено, щзо досліджувані одиниці вживаються як у близьких, так і у віддалених науково-технічних галузях. За семантичною ознакою виокремлено три типи міжгалузевих спеціальних одиниц: терміни-еврисеманти, терміни-полісеманти, терміни-омоніми.

Ключові слова: науково-технічна термінологія, міжгалузевий термін, термін-еврисемант, термін-полісемант, термін-омонім, ретермінологізаuія.

\section{Krymets O. Interdisciplinary Terms in Ukrainian Scientific and Technical} Terminology. The relevance of the research lies in the study of intrasystem potentialities of scientific and technical terms, which are a powerful source of the development of terminology and the emergence of interdisciplinary terms used in various fields of science and technology in one or more meanings.

The purpose of the article is to study the specific features of interdisciplinary terms, find out the peculiarities of the development of their meanings, identify common features, analyse definitions in various fields of science and technology, as well as to determine the types of interdisciplinary terms.

The study clarifies the specific features of interdisciplinary terms that are used with different meanings in several industries or denote one broad concept used in many scientific and technical fields. There are three types of interdisciplinary terms: 1. Eurosemy terms, which have a wide meaning and are used in many scientific and technical fields. Such units denote a variety of special subjects, processes, and patterns in various fields of science and technology. 2. Polysemantic terms used in different scientific and technical fields with different meanings that are interconnected. The emergence of such terms is caused by the development of intrasystem potentialities of terminology and the reterminologization of special names. 3. Terms-homonyms used in different fields and whose meanings are not related. Such terms occur either as a result of splitting of the meanings of polysemantic words, or due to the coincidence of two or more words.

Interdisciplinary terms are the result of the reintegration of special units from different scientific and technical fields. Under the influence of external and internal 
linguistic factors, the meanings of existing terms are reinterpreted, which leads to the emergence of new meanings that represent the concepts of other areas. As a result, there are interdisciplinary terms that denote the concepts of both similar and different spheres of human activity.

Key words: scientific and technical terminology, interdisciplinary term, eurosemy term, polysemantic term, term-homonym, reterminologization.

\section{Вступ}

Розгалуженість сучасної науково-технічної термінології сприяє тому, що нові сфери науки і техніки для найменування нових понять продуктивно використовують наявні термінологічні одиниці, що за поняттєвою сферою тісно з ними пов'язані. Реалізація внутрішньосистемних можливостей науково-технічних спеціальних назв $є$ потужним джерелом розвитку термінології, унаслідок чого розвивається зовнішньо або внутрішньосистемна полісемія, тобто той самий термін може використовуватися в різних галузях науки і техніки з одним або кількома значеннями. Міжгалузеві терміни $€$ предметом дослідження багатьох наукових студій (Вакуленко: 2015; Даниленко, 1987; Лейчик, 2007). За ознакою семантичної узагальненості-конкретності В. Даниленко виокремлює міжнаукові терміни, до яких належать: 1) терміни, що формуються в межах комплексів наук (загальнотехнічні, загальнобіологічні та інші), і позначають базові поняття всього комплексу наук, наприклад, назви знарядь праці в складі загальнотехнічної термінології: апарати, блоки, інструменmu, роботи; 2) одиниці, що водночас використовуються в різних наукових дисциплінах, наприклад, термін асиміляція застосовують в етнографії та лінгвістиці (Даниленко, 1987). В. Лейчик зазначає, що семантика міжгалузевих термінів змінюється в кожній окремій галузі знань, набуваючи специфічних додаткових елементів значення (Лейчик, 2007).

Мета нашої розвідки - дослідити специфіку міжгалузевих термінів, з'ясувати особливості розвитку значень таких одиниць. Це передбачає розв'язання таких завдань: 1) виявити загальні ознаки міжгалузевих науково-технічних термінів; 2) проаналізувати їхні значення в різних сферах науки і техніки; 3) визначити типи міжгалузевих терміноодиниць. 


\section{Методи дослідження}

У дослідженні застосовано аналітико-описовий метод для вивчення кожної термінологічної одиниці в структурному й семантичному аспектах, а також методи дефінітивного аналізу для дослідження плану змісту українських науково-технічних термінів та уточнення їхньої семантичної структури. Для узагальнення й класифікації спеціальних одиниць залучено методи номінативного, елементи когнітивного аналізу та опозиційний метод.

\section{Виклад основного матеріалу}

Міжгалузеві терміни визначають як спеціальні одиниці, що їх використовують у кількох близьких або віддалених галузях науковотехнічної діяльності людини. Специфіка цих термінів виявляється в тому, що вони функціюють з різними значеннями в різних галузях або позначають одне поняття, яке вживається в кількох науково-технічних сферах. Можна виокремити такі типи міжгалузевих термінів: 1) терміни-еврисеманти, що мають широке значення і вживаються в багатьох науково-технічних галузях: апарат, механізм, машина, прилад, пристрій, деталь, корпус; 2) терміни-полісеманти, які використовують у різних науково-технічних сферах з різними значеннями, що пов'язані між собою: барабан, важіль, диполь, зонд; 3) терміниомоніми, значення яких не пов'язані між собою і вживаються в різних

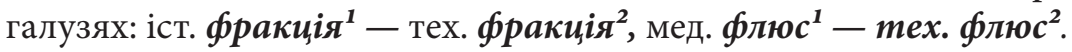

Перший тип міжгалузевих термінів характеризується наявністю широкого значення: npucmpiŭ - 'пристосування, обладнання, за допомогою якого виконується яка-небудь робота або спрощується, полегшується певний виробничий процес' (ВТССУМ), машина 'механізм або сукупність механізмів, що здійснюють певні доцільні рухи для перетворення енергії, виконання робіт або збирання, обробки і використання інформації (CCIC). У семантичній структурі цих термінів $€$ інтегральна сема узагальненого характеру, зокрема для терміна прилад - це сема «пристосування», машина - сема «механізм». Такі одиниці здатні позначати велику кількість різноманітних спеціальних предметів, призначених для виконання певних дій, операцій у різних сферах науки і техніки. Серед термінів-еврисемантів ми виявили як однозначні, так і багатозначні терміни, зокрема об’єкт: '1. філос. Пізнавана дійсність, що існує поза свідомістю 
людини і незалежно від неї. 2. Явище, предмет, особа, що на них спрямовано певну діяльність, увагу и т. ін. // Предмет наукового і т. ін. дослідження, спеціальної зацікавленості, компетенції. 3. спец. Певна одиниця (споруда, підприємство, ділянка місцевості й т. ін.) господарського чи оборонного значення' (CCIC).

Конкретизувати своє значення еврисемічний термін може лише в певному науково-технічному контексті. Головною ознакою терміна-еврисеманта $€$ те, що він може вживатися в різних галузях з тим самим значенням.

Полісеманти становлять найпоширеніший тип міжгалузевих термінів, що вживаються в кількох сферах науки і техніки з різними значеннями. У військовій галузі термін ежектор позначає 'механізм у вогнепальній зброї, який автоматично викидає стріляний патрон' (АУТСОТІП), а в техніці - 'струминний насос для переміщення рідин, газів, пари або сипких тіл, дія якого грунтується на ежекції, тобто змішуванні двох середовищ (пари і води), з яких одне, перебуваючи під тиском, діє на друге і виштовхує його у певному напрямку' (ТСТЦПВ).

Міжгалузеві терміни-полісеманти виникають унаслідок вторинної номінації наявних термінів, як близьких, так і віддалених сфер. Розвиток внутрішньосистемних можливостей зокрема технічної термінології спричиняє ретермінологізацію спеціальних назв техніки й появу міжгалузевих технічних термінів: валик, конвертор, тестер, брандмауер, ресивер, стопор, кодек, тонжерон, ипур. Термін конвертор у галузі електротехніки позначає: 'одноякірний перетворювач електричного струму’ (ВТССУМ), а в комп’ютерній техніці 'програма або пристрій, що перетворює дані з однієї форми на іншу, еквіваленту першій’ (ВТССУМ). У галузі будівництва термін брандмауер позначає 'глуху стіну з вогнетривкого матеріалу, яка розділяє два будинки або проведена всередині одного великого будинку з протипожежною метою' (ВТССУМ), а в галузі комп'ютерної техніки 'систему чи комбінацію систем, яка для захисту створює границю між комп'ютером і мережею, двома або більше мережами, запобігаючи несанкціонованому потраплянню в мережу або попереджаючи про вихід із неї пакетів даних' (АУТСОТІП). Термін шиур у гірничій галузі позначає: 'вузький циліндричний отвір, що його висвердлюють у гірських породах і наповнюють вибуховою речовиною під час вибухових 
робіт’ (ВТССУМ). Шляхом перенесення значення на основі зовнішньої схожості утворився термін, який використовують у галузі металургії: 'отвір у горні шахтної печі для випускання рідких продуктів плавки' (ВТССУМ).

Міжгалузеві терміни виникають унаслідок переосмислення не лише термінів однієї сфери, а й термінів різних наукових, технічних або інших галузей діяльності людини, тобто відбувається реінтеграція: знання однієї сфери дійсності переноситься на поняття іншої. У системі технічної лексики функціонують терміни, що належать і до інших терміносистем: фізики (ехо, ємність, поляризація,диполь), математики (диференціал, коефіцієнт, параметр, проекиія, сегмент), медицини (виразка, свищ), астрономії (аберація, коліматор, рефлектор), анатоміі (вертлюг, діафрагма, пульпа, фібра), ботаніки (фотосинтез), фізіології (терморегулювання), бактеріології (вірус), геодезії (планшет), метеорології (ииклон), хімії (інгібування), а також до таких сфер діяльності людини, як військова (арматура, батарея, гармата, катапульта), морська (дрейф, стапель, стренга), музична (амбушур, голосник, барабан, дека), кулінарна (ароматизувати, підлва), кравецтво (иліи), взуттєве виробництво (бутор, штихмас).

Терміни певної галузі науки і техніки, потрапляючи до іншої галузі, зазнають смислових змін, хоча семантичний стрижень терміна залишається тим самим. У ролі семантичного стрижня виступає сема-мотиватор, що є підгрунтям творення нового значення і може бути ядерною або периферійною в семних структурах вихідного й похідного значень. Термін диполь у фізиці має таке значення: 'два однакові за величиною і протилежні за знаком заряди, розташовані на деякій відстані один від одного' (ВТССУМ). Унаслідок семантичної модифікації цього значення виник технічний термін диполь, що позначає: 'радіо. Антена у вигляді двох симетрично розташованих провідників' (СДЕАПЕМ). Семантичне перетворення відбулося на підставі однакової кількості складників, сема-мотиватор - «два» в структурі значень фізичного й технічного термінів є диференційною.

Інтеграція термінів може відбуватися як між близькими галузями так і між досить віддаленими: підлива в кулінарній галузі - 'рідка приправа до страви; соус', у техніці - 'рідина, розчин, якими щонебудь підливають' (ВТССУМ); вірус в бактеріології - ‘бакт. Один 
iз найдрібніших мікроорганізмів, що викликає інфекційне захворювання', в комп'ютерній техніці - 'програма, що здатна сама приєднуватися до інших програм комп'ютера та викликати збої в їхній роботі' (ВТССУМ); ииклон у метеорології - 'вихровий рух атмосфери зі зменшенням тиску повітря від периферії до центра вихору...' (ВТССУМ), а в техніці - 'апарат для очищення повітря' (ВТССУМ).

До третього типу міжгалузевих термінів належать терміни-омоніми, що їх уживають у різних сферах зі значеннями, що між собою не пов'язані: вольт $\boldsymbol{m}^{\mathbf{1}}$ (іт. Volta - на честь італійського фізика А. Вольти) - 'міжнародна одиниця електричної напруги, електричного потенціалу, різниці електричних потенціалів, електрорушійної сили (B)' - вольт ${ }^{2}$ (фр. volte - поворот, оберт) - '1. спорт. Об'їзд манежу по колу під час вправ із верхової їзди. 2. спорт. Ухилення від удару супротивника під час фехтування' (ВТССУМ).

У термінології, як і в загальновживаній лексиці, омоніми виникають двома шляхами: на основі розщеплення значень полісемантів й унаслідок випадкового збігу двох чи більше слів. Релевантними ознаками омонімії в термінології науковці вважають, по-перше, належність їх до різних термінологічних об’єднань, по-друге, відсутність семантичних зв'язків між значеннями термінів, однакових у плані ви-

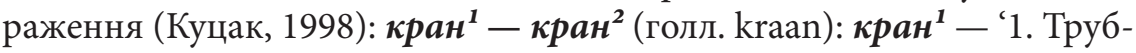
ка з затвором, прикріплена до водопроводу, газопроводу чи іншого резервуару для виливання рідини, випускання газу. 2. Пристрій осо-

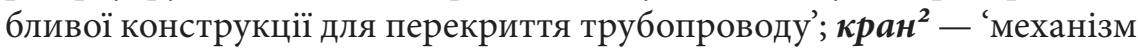
для підіймання й переміщення вантажів' (ВТССУМ); вузол ${ }^{\mathbf{1}}-\boldsymbol{в} \boldsymbol{в} \boldsymbol{з} \boldsymbol{\pi}^{\mathbf{2}}$ : вузол ${ }^{1}$ - 'з'єднані разом декілька деталей, що входять до більш складного механізму'; вузол $\boldsymbol{2}^{2}$ - 'міра швидкості морського транспорту, що дорівнює одній милі за годину (1,852 км./год.)' (ВТССУМ).

Міжгалузеві терміни-омоніми можуть позначати поняття як

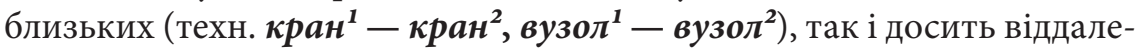

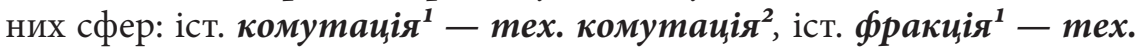

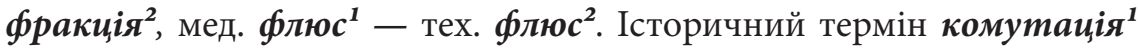
позначає 'процес заміни натурального оброку та панщини феодальною грошовою рентою, обумовлений розвитком товарно-грошових відносин' (ВТССУМ), а технічний термін комутація² - 'перемикання електричних кіл та їхніх частин; зміна напряму струму в цих колах’ (BТССУМ). 


\section{Висновки}

Отже, міжгалузеві терміни є результатом реінтеграції спеціальних одиниць різних науково-технічних галузей. Під впливом зовнішньо- й внутрішньолінгвістичних чинників значення наявних термінів переосмислюються, що спричиняє появу нових значень, які репрезентують поняття інших сфер. Унаслідок цього виникають міжгалузеві терміноодиниці, які позначають поняття як близьких, так і віддалених сфер діяльності людини. Дослідження цього шару спеціальної лексики дає підстави за семантичною ознакою виокремити три типи міжгалузевих термінів: еврисеманти, полісеманти та омоніми.

Перспективним уважаємо вивчення структури значення міжгалузевих термінів і специфіки семантичних процесів, що відбуваються під час творення нових одиниць.

\section{СПИСОК УМОВНИХ СКОРОЧЕНЬ}

АУТСОТІП - Пройдаков, Е., \& Теплицький Л. (2005). Англо-украӥнський тлумачний словник з обчислювальної техніки, Інтернету і програмування. Київ: СофтПрес.

ВТССУМ - Бусел, В. Т. (Ред.). (2001). Великий тлумачний словник сучасної української мови. Київ: Ірпінь.

СДЕАПЕМ - Хорольський, В. П. (Ред.). (1997). Словник-довідник з електротехніки, автоматики, промислової електроніки і метрології. Кривий Ріг: ВАТ Кривбасавтоматика.

ССІС - Нечволод, Л. (2007). Сучасний словник іншомовних слів. Харків: ПП «Торсінг плюс».

ТСТЦПВ - Сологуб, В. (2005). Тлумачний словник термінів целюлозно-паперового виробництва. Київ: Києво-Могилянська академія.

\section{ЛІТЕРАТУРА}

1. Вакуленко, М. (2015). Українська термінологія: комплексний лінгвістичний аналіз. Івано-Франківськ: Фоліант. 2. Даниленко, В. (1987). Терминология современного языка науки. В Терминоведение и терминография в индоевропейских языках (c. 61-66). Владивосток: ДВО АН СССР. 3. Куцак, Г. (1998). Міжгалузева термінологічна омонімія. Украӥнська термінологія і сучасність, 3, 74-76. 4. Лейчик, В. (2007). Терминоведение: предмет, методы, структура. Москва: URSS; Изд-во ЛКИ.

\section{REFERENCES}

1. Vakulenko, M. (2015). Ukrainska terminolohiia: kompleksnyi linhvistychnyi analiz [Ukrainian terminology: complex linguistic analysis]. Ivano-Frankivsk: Foliant [in Ukrainian]. 2. Danilenko, V. (1987). Terminologiya sovremennogo yazyka nauki [Terminology of the modern language of science]. Terminovedenie i terminografiya $v$ indoevropejskix yazykax - Terminology and terminogtaphy in Indo-European languages (pp. 61-66). 
Vladivostok: DVO AN SSSR [in Russian]. 3. Kutsak, H. (1998). Mizhhaluzeva terminolohichna omonimiia [Interdisciplinary terminological homonymy]. Ukrainska terminolohiia $i$ suchasnist - Ukrainian terminology and modernity, 3, 74-76 [in Ukrainian]. 4. Lejchik, V. (2007). Terminovedenie: predmet, metody, struktura [Terminology: subject, methods, structure]. Moskva: URSS; Izd-vo LKI [in Russian].

Кримець Оксана Михайлівна - кандидат філологічних наук, доцент, доцент кафедри української, російської мов та прикладної лінгвістики, Національний технічний університет «Харківський політехнічний інститут»; вул. Кирпичова, 2, м. Харків, 61000, Україна.

Tel.: +38-050-186-12-03

E-mail: oksana.krim@ukr.net

https://orcid.org/0000-0002-8401-3540

Krymets Oksana Mykhailivna - Ph.D. in Philology, Docent, Associate Professor at the Department of Ukrainian and Russian Languages and Applied Linguistics, National Technical University“ Kharkiv Polytechnic Institute”; Kyrpychov Str., 2, Kharkiv, 61000, Ukraine.

Надійшла до редакції 05 серпня 2020 року

\section{CITATION}

ДСТУ 8302:2015: Кримець О. М. Міжгалузеві терміни в українській науковотехнічній термінології. Лінгвістичні дослідження: зб. наук. пр. Харк. нац. пед. ун-ту імені Г. С. Сковороди. Харків, 2020. Вип. 53. С. 192-199. DOI: https:/doi.org/10.34142/ 23127546.2020.53.17

APA: Кримець, О. М. (2020). Міжгалузеві терміни в українській науково-технічній термінологіï. Лінгвістичні дослідження, 53, 192-199. DOI: https://doi.org/10.34142/ 23127546.2020.53.17 